\begin{tabular}{|c|c|}
\hline CRITICAL $\underset{\substack{\text { ECOSYSTEM } \\
\text { PARTERSHP FUND }}}{\cos }$ & $\begin{array}{l}\text { Western Ghats } \\
\text { Special Series }\end{array}$ \\
\hline
\end{tabular}

\section{BLACK MILDEWS (ASCOMYCETES) FROM SOUTHERN WESTERN GHATS OF PENINSULAR INDIA WITH DESCRIPTION OF 14 NEW SPECIES}

\section{V.B. Hosagoudar ${ }^{1}$, C. Jagath Thimmaiah ${ }^{2}$, M. Jayashankara ${ }^{3}$} \& A. Sabeena ${ }^{4}$

1,4 Jawaharlal Nehru Tropical Botanic Garden and Research Institute, Palode, Thiruvananthapuram, Kerala 695562, India

${ }^{2,3}$ Department of Studies and Research in Microbiology, Mangalore University post Graduate Centre, Cauvery Campus, Madikeri, Kodagu, Karnataka 571201 India

${ }^{1}$ vbhosagoudar@rediffmail.com (corresponding author), ${ }^{2}$ jgtct@rediffmail.com, 33jayashankara@yahoo.com

This paper gives an account of 15 black mildew fungi collected from Kodagu in Karnataka and Kollam in Kerala states. Of these, Asterina cassiigena, A. chrysophylligena, A. hemidesmi, A. ushae, A. thevalakkaraensis, $A$. vitacearum, Asterostomella derridicola, A. vernoniae, Prillieuxina humboltiae, Echinodella mimusopsidis, Mahanteshamyces litseae, Sarcinella bischofiae, S. pogostemonis and $S$. securinegae are new species, while Asterina antidesmatis forms a new record for India.

\section{Description of species}

Asterina antidesmatis Petrak, Sydowia 12: 472, 1959. (Fig. 1)

Materials examined: TBGT 5814, 09.i.2010, on leaves of Antidesma sp. (Stylaginaceae), Hoddur, Kodagu, Karnataka, coll. C. Jagath Thimmiah.

This species is recorded here for the first time from
India (Hosagoudar 2012).

Colonies amphigenous, thin, up to $2 \mathrm{~mm}$ in diameter, confluent. Hyphae substraight to flexuous, branching opposite to irregular at acute to wide angles, loosely to closely reticulate, cells $25-37 x$

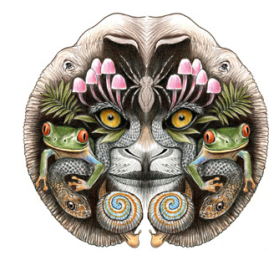

ISSN

Online 0974-7907 Print 0974-7893

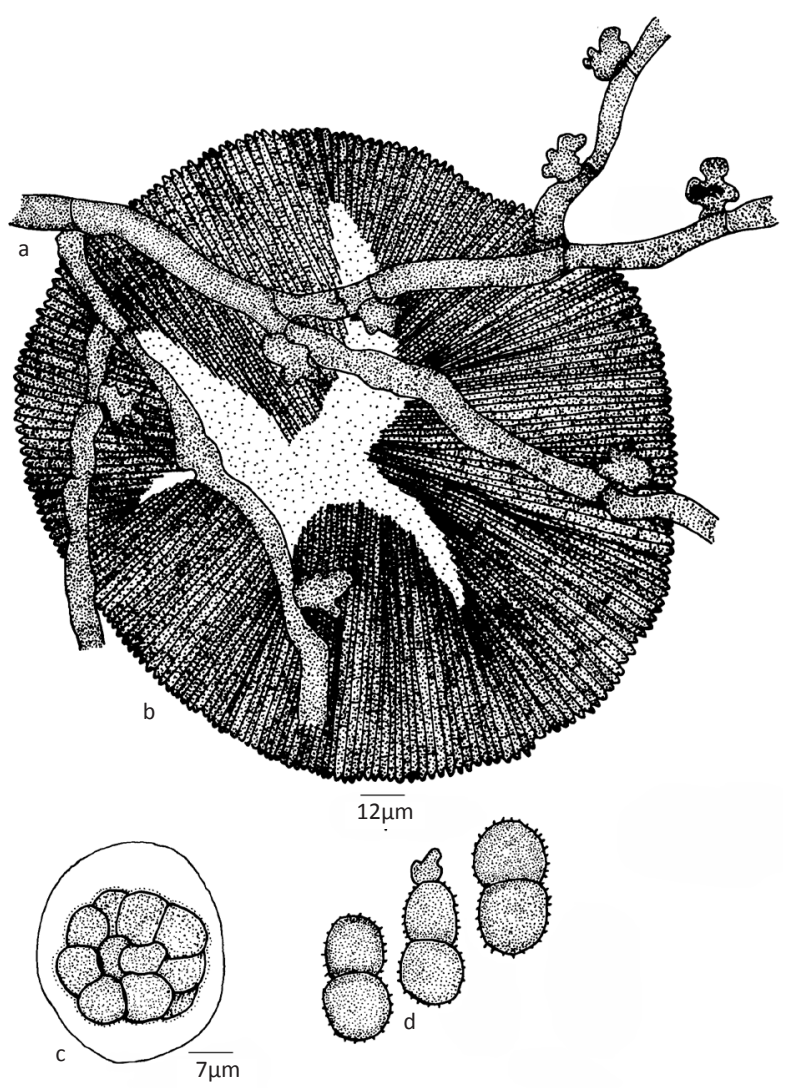

Figure 1. Asterina antidesmatis

a - Appressoriate mycelium; b - Thyriothecium; c - Ascus; d - Ascospores

DOI: http://dx.doi.org/10.11609/JoTT.03262.3661-69

Editor: R.K. Verma, Tropical Forest Research Institute, Jabalpur, India.

Date of publication: 26 February 2013 (online \& print)

Manuscript details: Ms \# 03262 | Received 20 July 2012 | Final received 06 January 2013 | Finally accepted 15 February 2013

Citation: Hosagoudar, V.B., C.J. Thimmaiah, M. Jayashankara \& A. Sabeena (2013). Black mildews (Ascomycetes) from southern Western Ghats of peninsular India with description of 14 new species. Journal of Threatened Taxa 5(2): 3661-3669; doi:10.11609/JoTT.03262.3661-69

Copyright: (c) Hosagoudar et al. 2013. Creative Commons Attribution 3.0 Unported License. JoTT allows unrestricted use of this article in any medium, reproduction and distribution by providing adequate credit to the authors and the source of publication.

Funding: Jawaraharlal Nehru Tropical Botanic Garden and Research Institute, Palode, Thiruvananthapuram, Kerala.

Competing Interest: None.

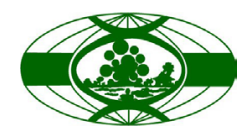

Acknowledgements: We are grateful to Dr, P.G. Latha, Director, JNTBGRI, Palode for the facilities. C. Jagath Thimmaiah is grateful to UGC FIP Fellowship.

The publication of this article is supported by the Critical Ecosystem Partnership Fund (CEPF), a joint initiative of l'Agence Française de Développement, Conservation International, the European Commission, the Global Environment Facility, the Government of Japan, the MacArthur Foundation and the World Bank. 
5-7 $\mu \mathrm{m}$. Appressoria alternate to unilateral, antrorse to subantrorse, sublobate to deeply lobate, 5-10 x 5-10 $\mu \mathrm{m}$; thyriothecia, scattered, orbicular, up to $160 \mu \mathrm{m}$ in diameter, stellately dehisced at the centre; asci globose, octosporous, up to $22 \mu \mathrm{m}$ in diameter; ascospores, conglobate, uni septate, constricted at the septum, 15$20 \times 5-10 \mu \mathrm{m}$, wall echinulate at maturity.

\section{Asterina cassiigena Hosag., C. Jagath Thimmaiah \& A. Sabeena sp. nov.}

(Fig. 2) (MycoBank 803144)

Materials examined: Holotype: TBGT 5838, 08.i.2010, Hoddur, Kodagu, Karnataka, coll. C. Jagath Thimmiah.

Asterina cifferiana Petrak, A. contigua Sydow are known on the members of family Caesalpiniaceae (Hosagoudar \& Abraham 2000). However, Asterina cassiigena differs from both in having distantly appressoria.

Etymology: Specific epithet based on the host genus.

Colonies epiphyllous, subdense to dense, up to $3 \mathrm{~mm}$ in diameter, confluent. Hyphae straight to substraight, on leaves of Cassia glauca Lam. (Caesalpiniaceae),

branching opposite to irregular at acute to wide angles, loosely to closely reticulate, cells $15-27 \times 2-5 \mu \mathrm{m}$. Appressoria alternate, unicellular, distantly placed, antrorse to subantrorse, globose, oblong, entire, 5-7 x 5-10 $\mu \mathrm{m}$. Thyriothecia, scattered, orbicular, up to $240 \mu \mathrm{m}$ in diameter, stellately dehisced at the centre, margin crenate to fimbriate; asci globose, octosporous, up to $25 \mu \mathrm{m}$ in diameter; ascospores brown, conglobate, uniseptate, constricted at the septum, 20-22 x 7-10 $\mu \mathrm{m}$, wall smooth.

\section{Asterina chrysophylligena Hosag., C. Jagath Thimmaiah \& A. Sabeena sp .nov.}

(Fig. 3) (MycoBank 803145)

Material examined: Holotype: TBGT 5761, 26.i.2011, on leaves of Chrysophyllum roxburghii G. Don (Sapotaceae), Madikeri, Kodagu, Karnataka, coll. C. Jagath Thimmaiah.

Asterina chrysophylli Henn. is known on this host genus and Theissen (1913) has given the detailed description of this species. A. chrysophylligena differs from $A$. chrysophylli in having distinctly smaller ascospores (14-16 x 9-4 vs. 28-34 x 12-15 $\mu \mathrm{m}$ ).

Etymology: Specific epithet based on the host

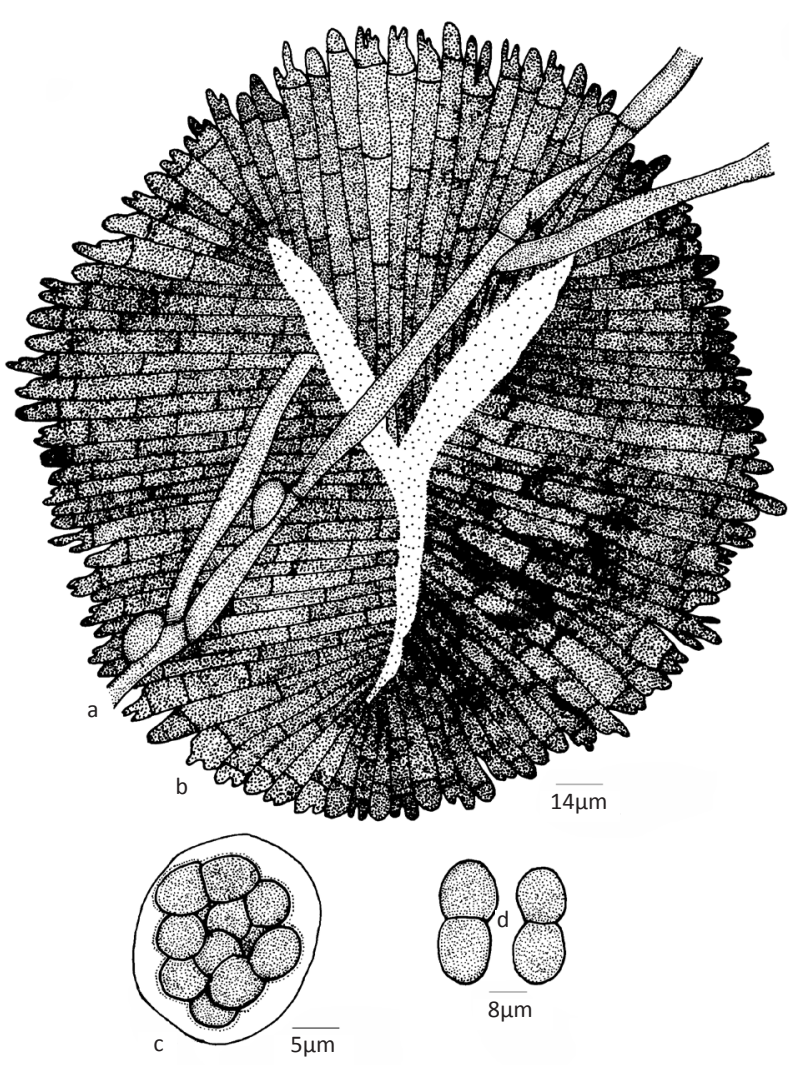

Figure 2. Asterina cassiigena sp. nov.

a - Appressoriate mycelium; b - Thyriothecium; c - Ascus;

$\mathrm{d}$ - Ascospores

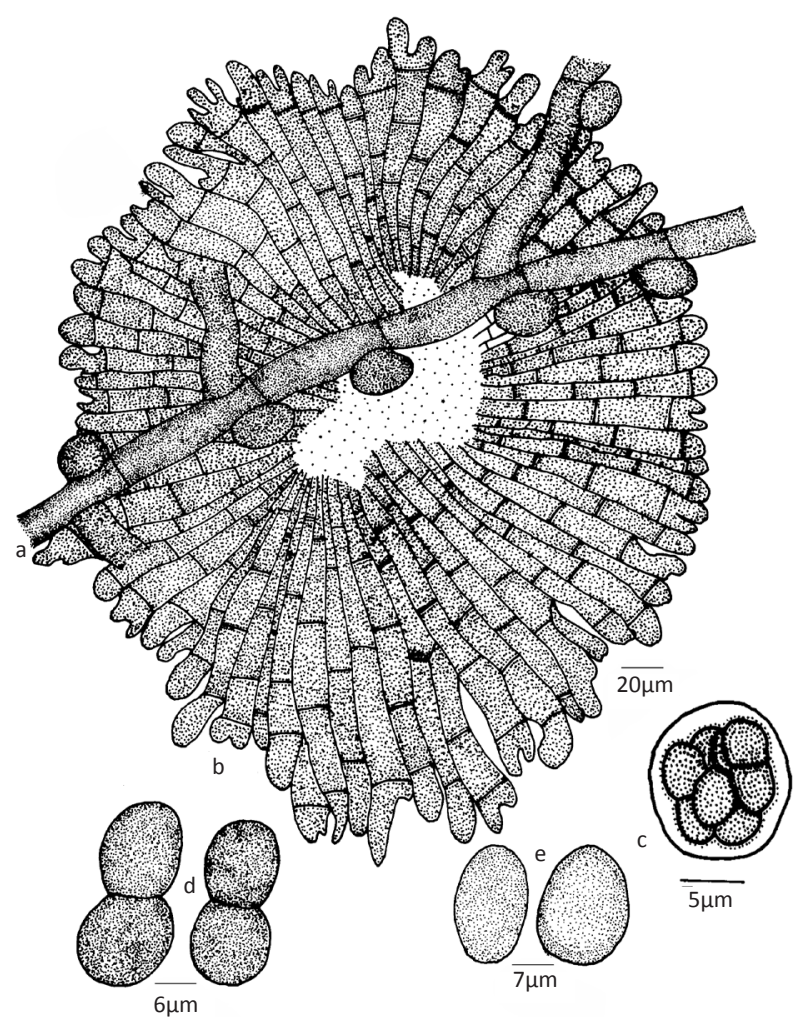

Figure 3. Asterina chrysophylligena sp. nov.

a - Appressoriate mycelium; b - Thyriothecium; c - Ascus;

d - Ascospores 
genus.

Colonies epiphyllous, subdense, up to $4 \mathrm{~mm}$ in diameter, confluent. Hyphae straight to substraight, branching alternate to irregular at acute to wide angles, loosely to closely reticulate, cells $16-32 \times 4-7 \mu \mathrm{m}$. Appressoria alternate, unilateral, unicellular, globose, entire, 4-10 x 8-10 $\mu \mathrm{m}$. Thyriothecia scattered to loosely grouped, orbicular, up to $300 \mu \mathrm{m}$ in diameter, stellately dehisced at the centre, margin fimbriate, fringed hyphae small; asci few, globose, up to $30 \mu \mathrm{m}$ in diameter; ascospores brown, conglobate, oblong, uniseptate, constricted at the septum, 24-30 x 11-15 $\mu \mathrm{m}$, wall smooth. Pycnothyriospores oval to globose, brown, 14-16 x 10-14 $\mu \mathrm{m}$.

\section{Asterina hemidesmi Hosag., C. Jagath Thimmaiah \& A. Sabeena sp. nov.}

(Fig. 4) (MycoBank 803146)

Materials examined: Holotype: TBGT 5829, 13.i.2010, on leaves of Hemidesmus sp. (Periplocaceae), Hodur, Kodagu, Karnataka, coll. C. Jagath Thimmiah.

This forms the first report on this host genus (Doidge 1942; Stevens \& Rayan 1939).

Etymology: Specific epithet based on the host genus.

Colonies epiphyllous, subdense, up to $4 \mathrm{~mm}$ in

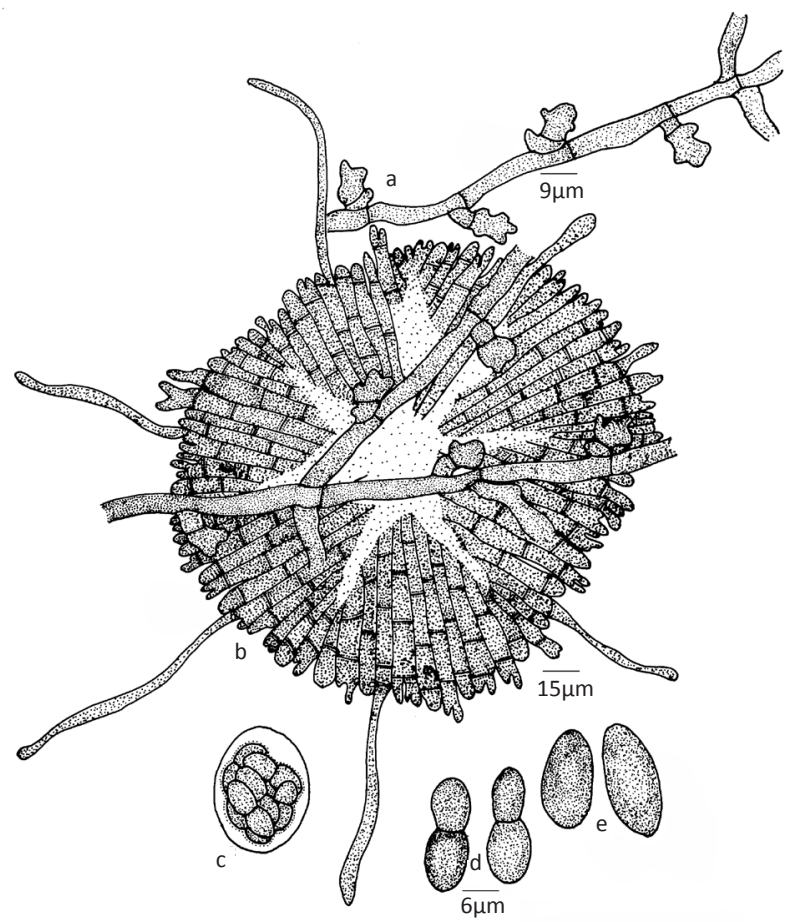

Figure 4. Asterina hemidesmi sp. nov.

a - Appressoriate mycelium; b - Thyriothecium; c - Ascus;

d - Ascospores diameter, confluent. Hyphae substraight to flexuous, branching opposite to irregular at acute to wide angles, loosely to closely reticulate, cells $15-27 \times 3-5 \mu \mathrm{m}$. Appressoria alternate, opposite (10\%) to unilateral, two celled, antrorse to subantrorse, straight to slightly curved, 9-14 $\mu \mathrm{m}$ long; stalk cells cylindrical to cuneate, often gibbous, 3-6 $\mu \mathrm{m}$ long; head cells ovate, globose, oblong, angular to sublobate, 4-10 x 4-8 $\mu \mathrm{m}$. Thyriothecia grouped in the centre of the colonies, orbicular, up to $180 \mu \mathrm{m}$ in diameter, stellately dehisced at the centre, margin crenate to fimbriate, fringed hyphae flexuous; asci ovate, globose, octosporous, 16$22 \mu \mathrm{m}$ in diameter; ascospores, conglobate, uniseptate, constricted at the septum, 14-18 x 6-8 $\mu \mathrm{m}$, wall smooth. Pycnothyriospores ovate, pyriform, 12-16 x 8-10 $\mu \mathrm{m}$.

\section{Asterina ushae Hosag., C. Jagath Thimmaiah}

\& G.R. Archana sp. nov.

(Fig. 5) (MycoBank 803148)

Material examined: Holotype: TBGT 5756, 27.viii.2010, on leaves of Glochidion bourdillonii Gamble (Euphorbiaceae), Hoddur, Kodagu, Karnataka, coll. C. Jagath Thimmaiah.

Oblong, narrowly cylindrical, entire, angular to sublobate head cells of the appressoria distinguishes this species from rest of the Asterina species known on the members of Euphorbiaceae (Hosagoudar 2012).

Etymology: Species named in honour of Mrs. Dr. Usha Mane (Machale), for her selfless service to mankind.

Colonies epiphyllous, thin, up to $2 \mathrm{~mm}$ in diameter, confluent. Hyphae straight to substraight, branching opposite, alternate to irregular at acute to wide angles, loosely reticulate, cells $19-37 \times 3-5 \mu \mathrm{m}$. Appressoria

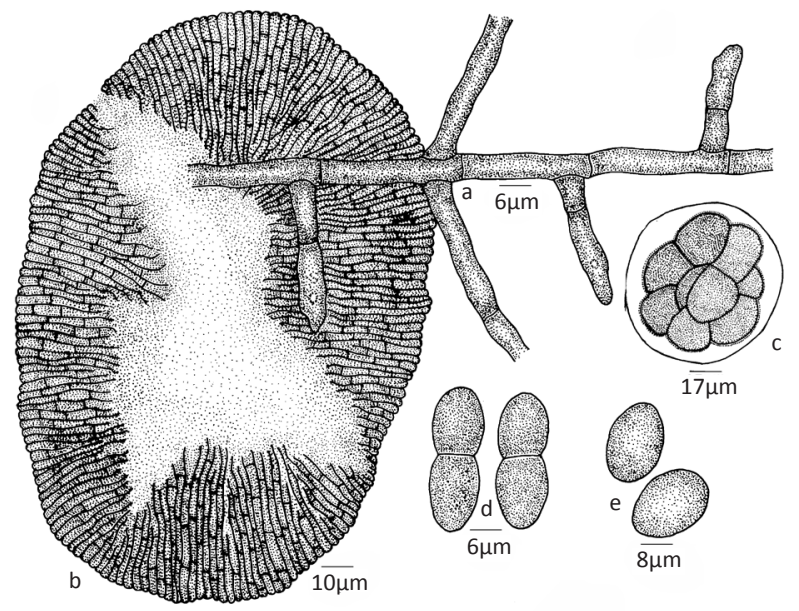

Figure 5. Asterina ushae sp. nov.

a - Appressoriate mycelium; b - Thyriothecium; c - Ascus;

d - Ascospores 
alternate, unilateral, two celled, antrorse, subantrorse, straight to slightly curved, 10-22 $\mu \mathrm{m}$ long; stalk cells cylindrical to cuneate, 3-8 $\mu \mathrm{m}$ long; head cells ovate, oblong, entire to angular, 6-15 × 3-6 $\mu \mathrm{m}$. Thyriothecia scattered, orbicular, stellately dehisced at the centre, up to $120 \mu \mathrm{m}$ in diameter, margin crenate; asci oval to globose, octosporous, up to $32 \mu \mathrm{m}$ in diameter; ascospores conglobate, oblong to cylindrical, uniseptate, constricted at the septum, 16-23 x 7-11 $\mu \mathrm{m}$, wall smooth. Pycnothyriospores brown, oval, entire, 15-24x 10-15 $\mu \mathrm{m}$.

\section{Asterina thevalakkaraensis Hosag. \& R. Bindu sp. nov.} (Fig.6) (MycoBank 803149)

Material examined: Holotype: TBGT 6123, 15.i.2012, on leaves of Hydnocarpus sp. (Flacourtiaceae), Thevalakkara, Karunagappally, Kollam, coll. R. Bindu.

Based on the unicellular appressoria, this species can be compared with $A$. granulose (Hansf. ) Hosag. et al. (Hosagoudar et al. 1996) but differs from it in distantly arranged, mostly alternately placed appressoria with entire margin in contrast to sublobate ones.

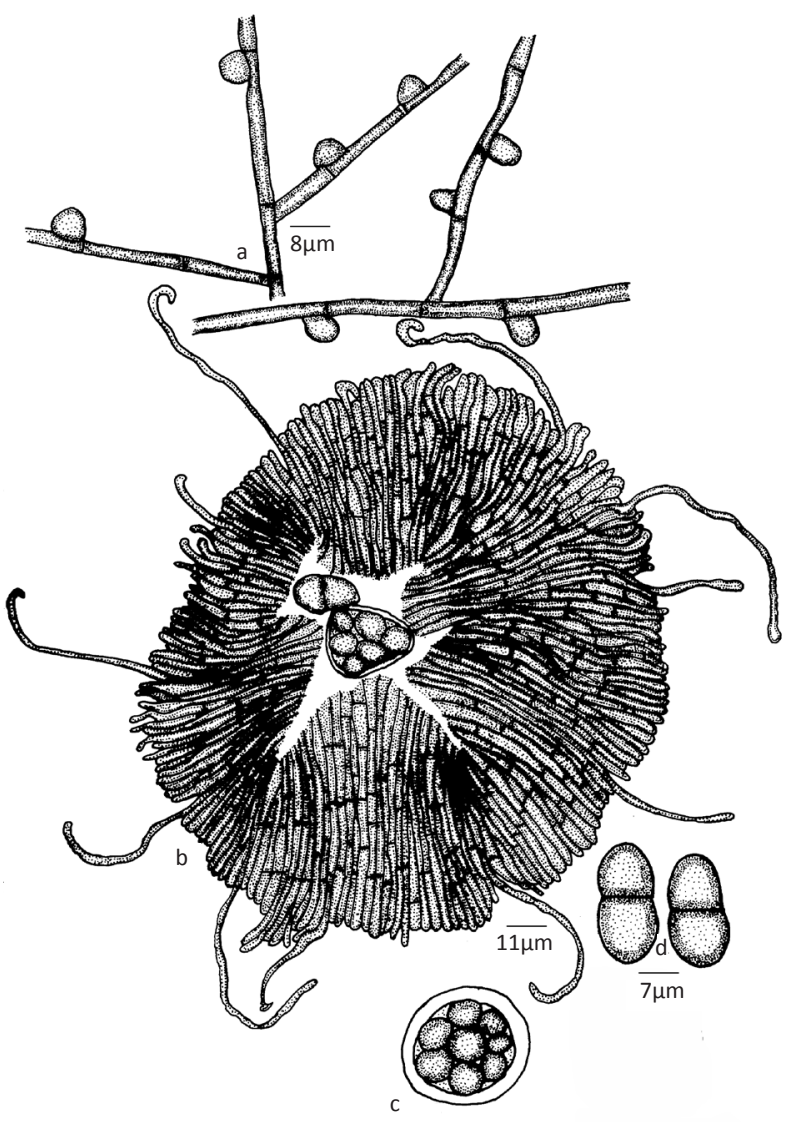

Figure 6. Asterina thevalakkaraensis sp. nov.

a - Appressoriate mycelium; b - Thyriothecium; c - Ascus;

d - Ascospores
Etymology: Specific epithet based on the collection locality.

Colonies amphigenous, mostly epiphyllous, about $2 \mathrm{~mm}$ in diameter. Hyphae straight, branching opposite to irregular at acute to wide angles, loosely reticulate, cells $12-16 \times 3-4 \mu \mathrm{m}$. Appressoria unicellular, distantly placed, alternate, unilateral, rarely opposite, oval to globose, entire, 6-17 × 7-10 $\mu \mathrm{m}$. Thyriothecia scattered, orbicular, stellately dehisced at the centre, up to $110 \mu \mathrm{m}$ in diameter, margin fimbriate, fringed hyphae few; asci globose, up to $29 \mu \mathrm{m}$ in diameter; ascospores conglobate, oblong to cylindrical, brown, uniseptate, constricted at the septum, $12-17 \times 5-7 \mu \mathrm{m}$.

\section{Asterina vitacearum Hosag., C. Jagath Thimmaiah \& A. Sabeena sp. nov.}

(Fig.7) (MycoBank 803155)

Materials examined: Holotype: TBGT 5800, 01.i.2010, on leaves of Cissus repens Lam. (Vitaceae), Hodur, Kodagu, Karnataka, coll. C. Jagath Thimmiah.

This species has slightly shorter ascospores but distinctly narrow ascospores. Usually thyriothecium develops on the mycelium or slightly lateral to the hyphae but in the present species, thyriothecia developed in the 1-3 celled stalk.

Etymology: Specific epithet based on the host

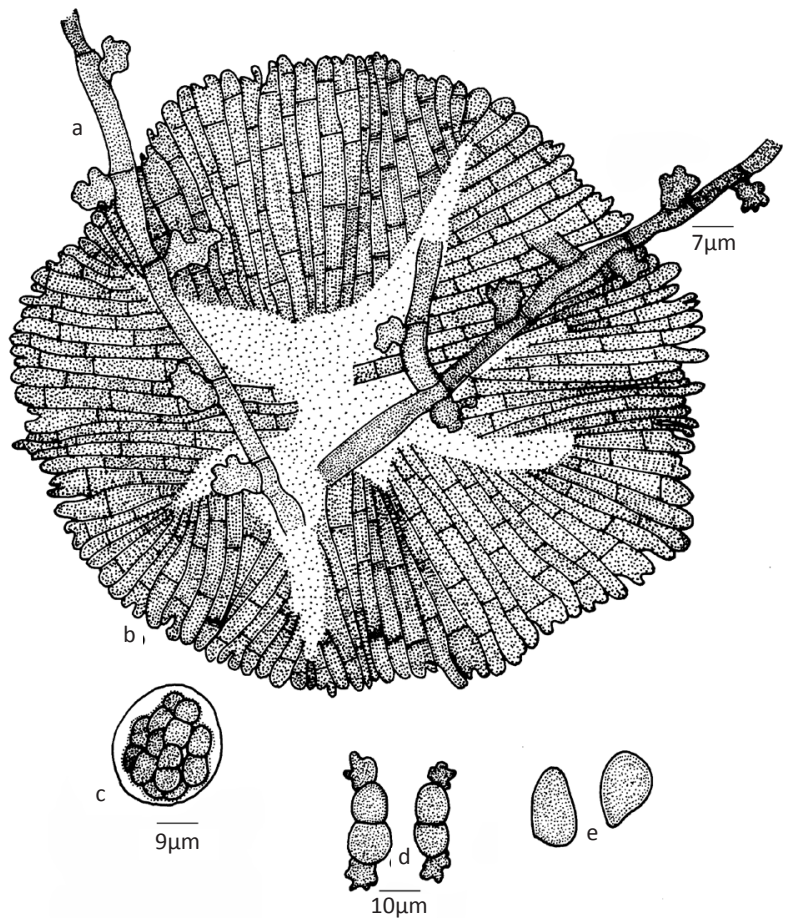

Figure 7. Asterina vitacearum sp. nov.

a - Appressoriate mycelium; b - Thyriothecium; c - Ascus;

d- Ascospores 
family.

Colonies epiphyllous, thin, up to $1 \mathrm{~mm}$ in diameter, confluent. Hyphae substraight to flexuous, branching opposite to irregular at acute to wide angles, loosely to closely reticulate, cells $12-20 \times 2-5 \mu \mathrm{m}$. Appressoria alternate to unilateral, unicellular, antrorse to subantrorse, sublobate to deeply lobate, 5-7 x 5-10 $\mu \mathrm{m}$. Thyriothecia scattered to grouped in the centre of the colony, orbicular, up to $100 \mu \mathrm{m}$ in diameter, stellately dehisced at the centre, margin crenate to fimbriate, fringed hyphae flexuous; asci globose, octosporous, up to $18 \mu \mathrm{m}$ in diameter; ascospores conglobate, brown, uniseptate, constricted at the septum, 12-20 x 5-7 $\mu \mathrm{m}$, wall smooth.

\section{Asterostomella derridicola Hosag., C. Jagath Thimmaiah \& A. Sabeena sp. nov.}

(Fig. 8) (MycoBank 803156)

Materials examined: Holotype: TBGT 5811, 06.ii.2010, on leaves of Derris canarensis (Dalz.) Baker (Fabaceae), Hodur, Kodagu, Karnataka, coll. C. Jagath Thimmiah.

Asterina derridis Henn., A. trachycarpa Syd. \& A. singaporensis Syd. are known on this host genus from Philippines and Singapore (Theissen 1913; Stevens \& Ryan 1939). But the present species differs from all these teleomorphs in having sublobate to lobate appressoria.

Etymology: Specific epithet based on the host genus.

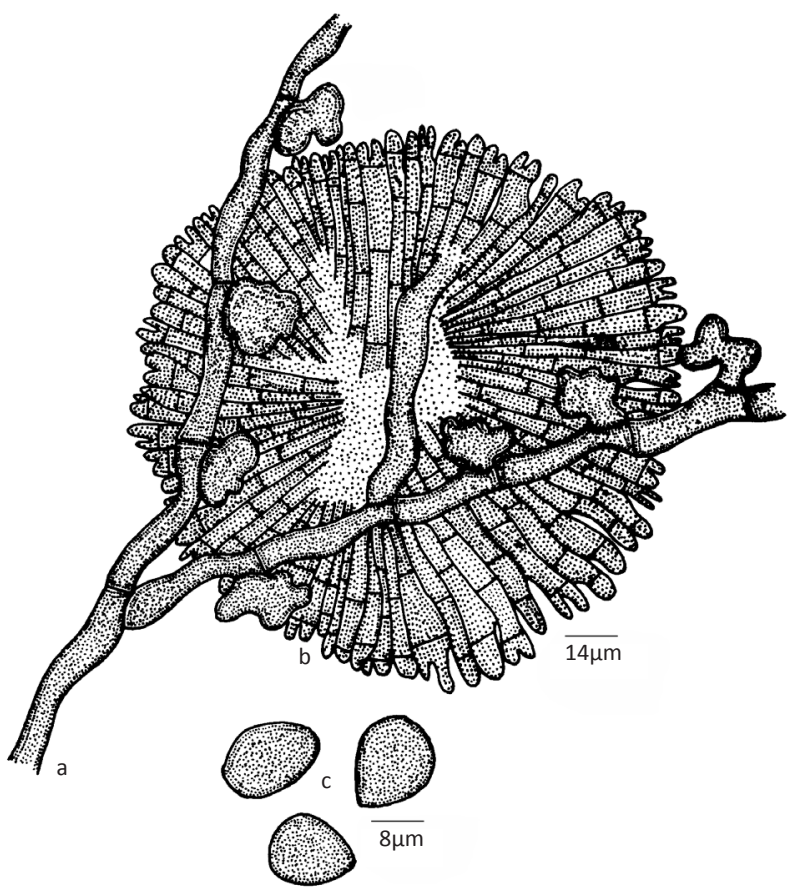

Figure 8. Asterostomella derridicola sp. nov.

a - Appressoriate mycelium; b - Pycnothyrium; c - Pycnothyriospores
Colonies epiphyllous, very thin, spreading, up to $2 \mathrm{~mm}$ in diameter, confluent. Hyphae substraight to flexuous, branching opposite to irregular at acute to wide angles, loosely reticulate, cells $12-25 \times 3-4 \mu \mathrm{m}$. Appressoria alternate to unilateral, antrorse to subantrorse, straight to curved, globose to clavate, sublobate to lobate, 5-12 x 5-12 $\mu \mathrm{m}$. Pycnothyria scattered, orbicular, up to $140 \mu \mathrm{m}$ in diameter, stellately dehisced at the centre; pycnothyriospores ovate, globose, unicellular, 12-15 x 7-12 $\mu \mathrm{m}$, wall smooth.

\section{Asterostomella vernoniae Hosag., C. Jagath Thimmaiah \& G.R. Archana sp. nov.}

(Fig. 9) (MycoBank 803157)

Material examined: Holotype: TBGT 5813, 09.i.2010, on leaves of Vernonia monosis Benth. ex C.B. Clarke (Asteraceae), Tadiyandamol, Kodagu, Karnataka, coll. C. Jagath Thimmaiah.

This is the first asterinaceous fungus on this host genus (Stevens \& Ryan 1939; Doidge 1942).

Etymology: Specific epithet based on the host genus.

Colonies epiphyllous, thin, crustose, up to $3 \mathrm{~mm}$ in diameter, confluent. Hyphae substraight to flexuous, branching opposite to irregular at acute to wide angles, loosely to closely reticulate, cells $11-29 \times 3-5$ $\mu \mathrm{m}$. Appressoria alternate to unilateral, sessile to slightly stipitate, globose, ovate, entire, 4-8 x 4-9 $\mu \mathrm{m}$. Pycnothyria scattered, orbicular, up to $75 \mu \mathrm{m}$ in diameter; stellately dehisced at the centre, margin fimbriate; pycnothyriospores brown, unicellular, ovate, pyriform, 16-24 x 8-13 $\mu \mathrm{m}$.

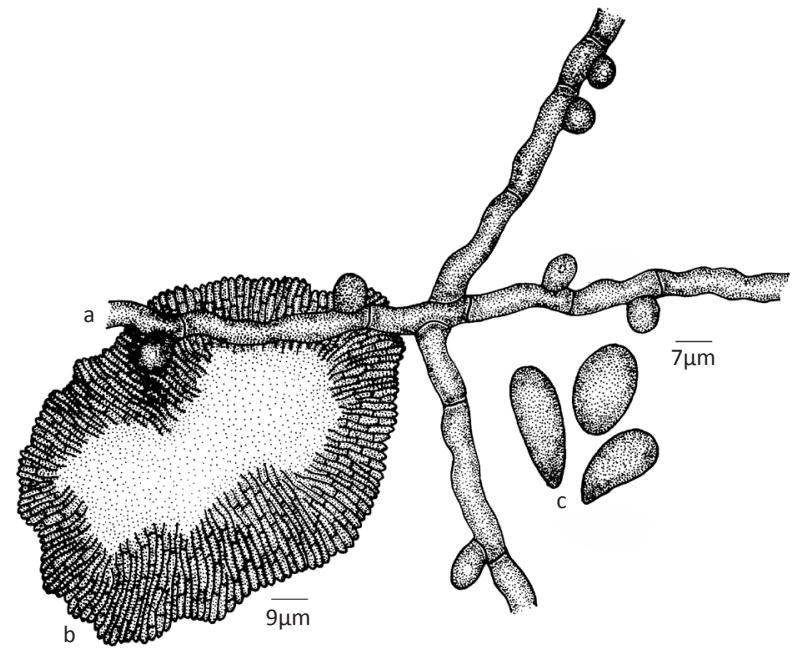

Figure 9. Asterostomella vernoniae sp. nov.

a - Appressoriate mycelium; b - Pycnothyrium; c - Pycnothyriospores 


\section{Prillieuxina humboltiae Hosag., C. Jagath Thimmaiah \& G.R. Archana sp. nov.}

(Fig. 10) (MycoBank 503150)

Materialexamined:Holotype:TBGT5791,01.viii.2010, on leaves of Humboltia sp. (Fabaceae), Sampaje Ghats, Kodagu, Karnataka, coll. C. Jagath Thimmaiah.

The genus Humboldtia is known to have three Lembosia species from the Western Ghats (Hosagoudar et al. 2009) but the present fungus differs from them in having orbicular thyriothecia and the mycelium being free from appressoria.

Etymology: Specific epithet based on the host genus.

Colonies hypophyllous, thin, crustose, up to $3 \mathrm{~mm}$ in diameter, confluent. Hyphae substraight, flexuous to slightly crooked, branching opposite to irregular at acute to wide angles, loosely to closely reticulate, cells 8-32 $x$ 3-5 $\mu \mathrm{m}$. Thyriothecia scattered to loosely grouped, orbicular, up to $245 \mu \mathrm{m}$ in diameter, stellately dehisced at the centre, margin fimbriate, fringed hyphae small; asci globose, octosporous, up to $28 \mu \mathrm{m}$ in diameter; ascospores conglobate, uniseptate, constricted at the septum, 20-24 x 9-12 $\mathrm{mm}$. Pycnothyriospores oval, pyriform, unicellular, 16-24 x 9-13 $\mu \mathrm{m}$.

\section{Echinodella mimusopsidis Hosag., C. Jagath Thimmaiah}

\& A. Sabeena sp. nov.

(Fig. 11) (MycoBank 803158)

Materials examined: Holotype: TBGT 5855, 31.i.2010, on leaves of Mimusops elengi L. (Sapotaceae), Hodur,

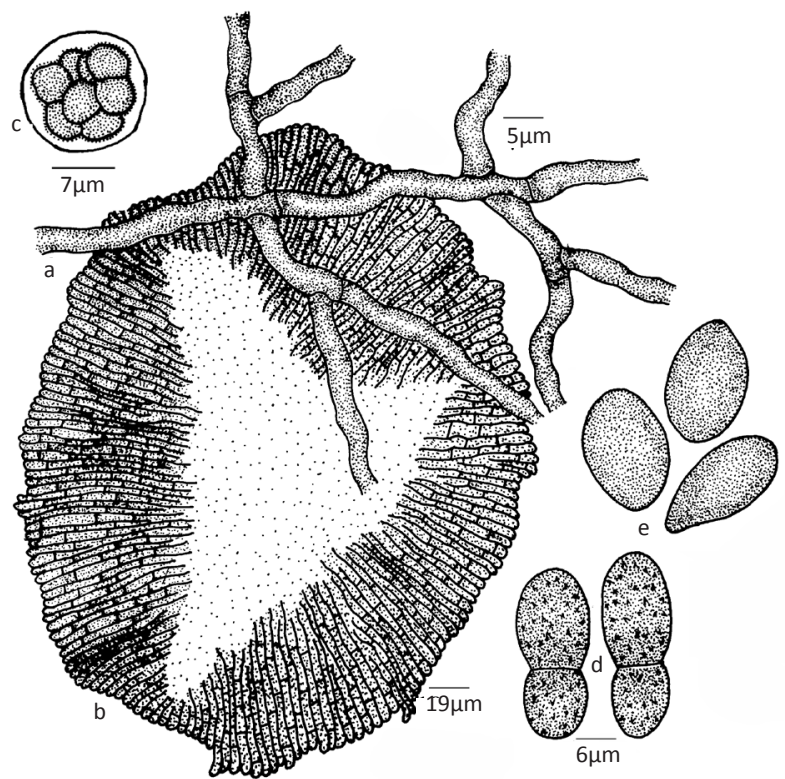

Figure 10. Prillieuxina humboltiae sp. nov.

a - Mycelium; b - Thyriothecium; c - Ascus; d - Ascospores;

e - Pycnothyriospores
Kodagu, Karnataka, coll. C. Jagath Thimmiah.

Prillieuxina mimusopsidis (Doidge) Ryan is known on this host genus (Steven \& Ryan 1939) but differs from it in having elongated thyriothecia with a centrally dissolved suture.

Etymology: Specific epithet based on the host genus.

Colonies hypophyllous, subdense, up to $6 \mathrm{~mm}$ in diameter, confluent. Hyphae substraight to flexuous, branching opposite to irregular at acute to wide angles, loosely reticulate, cells $20-27 \times 3-5 \mu \mathrm{m}$. Appressoria absent. Thyriothecia scattered, oval to elongated, 350$1100 \times 200-300 \mu \mathrm{m}$ in diameter, longitudinally dehisced at the centre, margin crenate; asci ovate, globose, octosporous, up to $27 \mu \mathrm{m}$ in diameter; ascospores conglobate, uniseptate, constricted at the septum, 27$30 \times 10-12 \mu \mathrm{m}$, wall smooth.

\section{Mahanteshamyces litseae Hosag., C. Jagath} Thimmaiah \& A. Sabeena sp. nov.

(Fig. 12) (MycoBank 803159)

Materials examined: TBGT 5815, 09.i.2010, on leaves of Litsea sp. (Lauraceae), Hodur, Kodagu, Karnataka, coll.

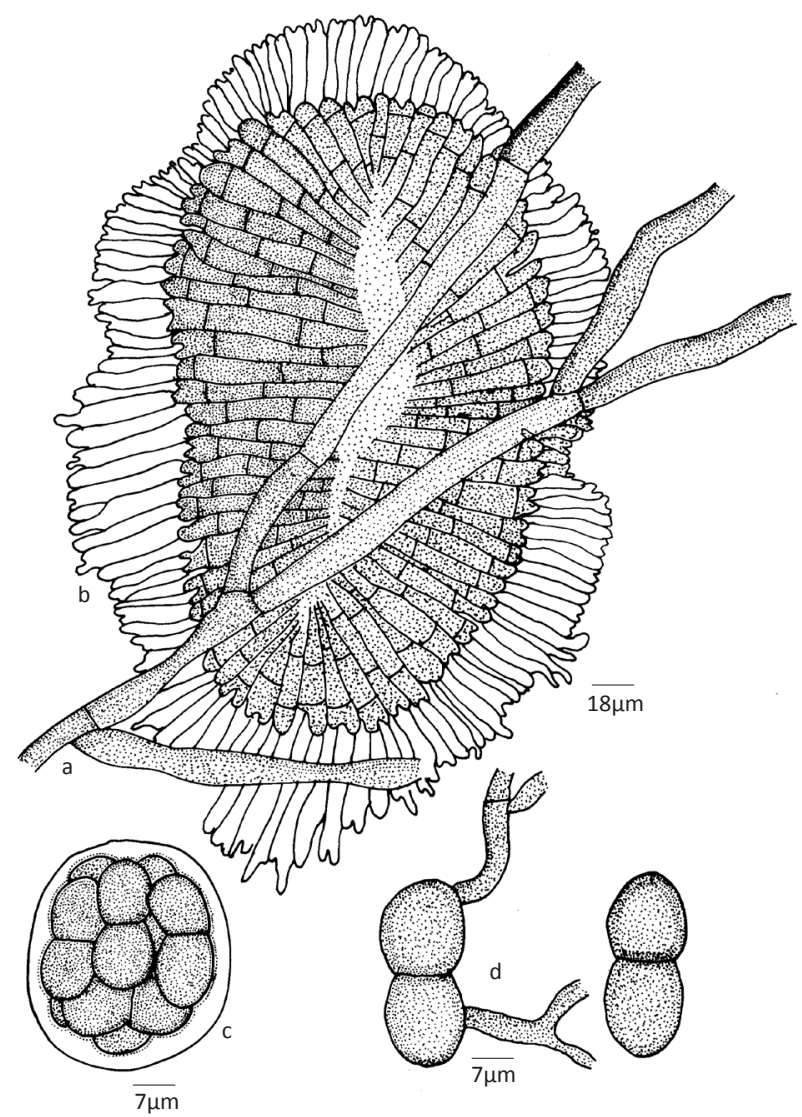

Figure 11. Echinodella mimusopsidis sp. nov.

a - Mycelium; b - Thyriothecium; c - Ascus; d - Ascospores 


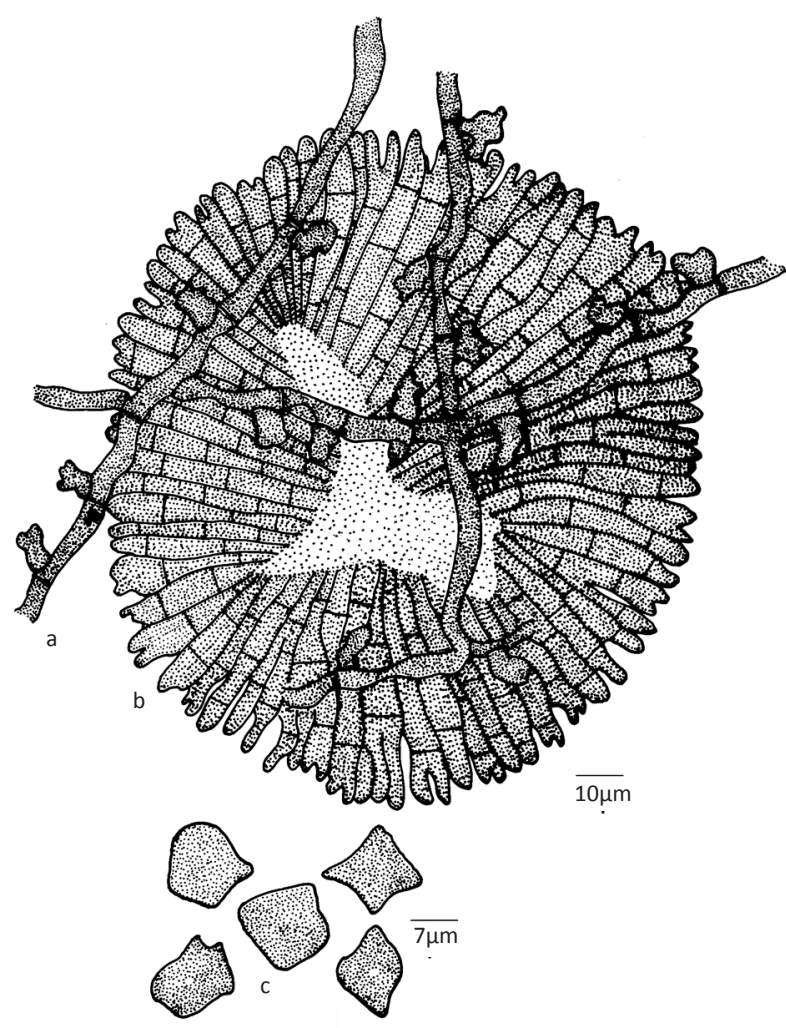

Figure 12. Mahanteshamyces litseae sp. nov.

a - Appressoriate mycelium; b - Pycnothyrium; c - Pycnothyriospores

\section{Jagath Thimmiah.}

This collection persisted only in its anamorph state with angular pycnothyriospores, belonging to the genus Mahanteshamyces. This forms the first report of the genus Mahanteshamyces on the members of the family Lauraceae (Hosagoudr et al. 2004).

Etymology: Specific epithet based on the host genus.

Colonies amphigenous, thin, spreading, up to $5 \mathrm{~mm}$ in diameter, confluent. Hyphae substraight to flexuous, branching opposite to irregular at acute to wide angles, loosely to closely reticulate, cells $12-25$ x 2-4 $\mu \mathrm{m}$. Appressoria unicellular, alternate, rarely opposite to unilateral, ovate, entire to sublobate, 5-7 $x$ 2-7 $\mu \mathrm{m}$. Pycnothyria scattered, orbicular, up to $120 \mu \mathrm{m}$ in diameter, stellately dehisced at the centre, margin crenate; pycnothyriospores unicellular, angular with 1-5 rounded marginal projections, 10-12 x 7-12 $\mu \mathrm{m}$, wall smooth.

\section{Sarcinella bischofiae Hosag., C. Jagath Thimmaiah \& A. Sabeena sp. nov.}

(Fig. 13) (MycoBank 803160)

Materials examined:Holotype:TBGT5805,30.xi.2010, on leaves of Bischofia javanica Blume (Euphorbiaceae), Madikeri, Kodagu, Karnataka, coll. C. Jagath Thimmiah.

This collection persisted in its Sarcinella state. Sarcinella indica Chandra et al. known on Sapium insigne from Uttar Pradesh, but the present collection accommodated in a new species based on its host specificity (Hosagoudar 2011).

Etymology: Specific epithet based on the host genus.

Colonies amphigenous, thin, confluent and cover most of the leaf surface. Hyphae substraight to flexuous, branching opposite to unilateral at acute to wide angles, loosely reticulate, cells $22-28 \times 5-8 \mu \mathrm{m}$. Appressoria scattered, alternate to unilateral, unicellular, globose, ovate, entire, 7-13 x 9-11 $\mu \mathrm{m}$. Sarcinella conidiophores produced laterally from the hyphae, single, straight, mononematous, 22-25 x 5-8 $\mu \mathrm{m}$; conidiogenous cells terminal, monoblastic, integrated, cylindrical; conidia charcoal black, blastic, terminal, solitary, ovate to globose, sarciniform, 2-5 celled, constricted at the

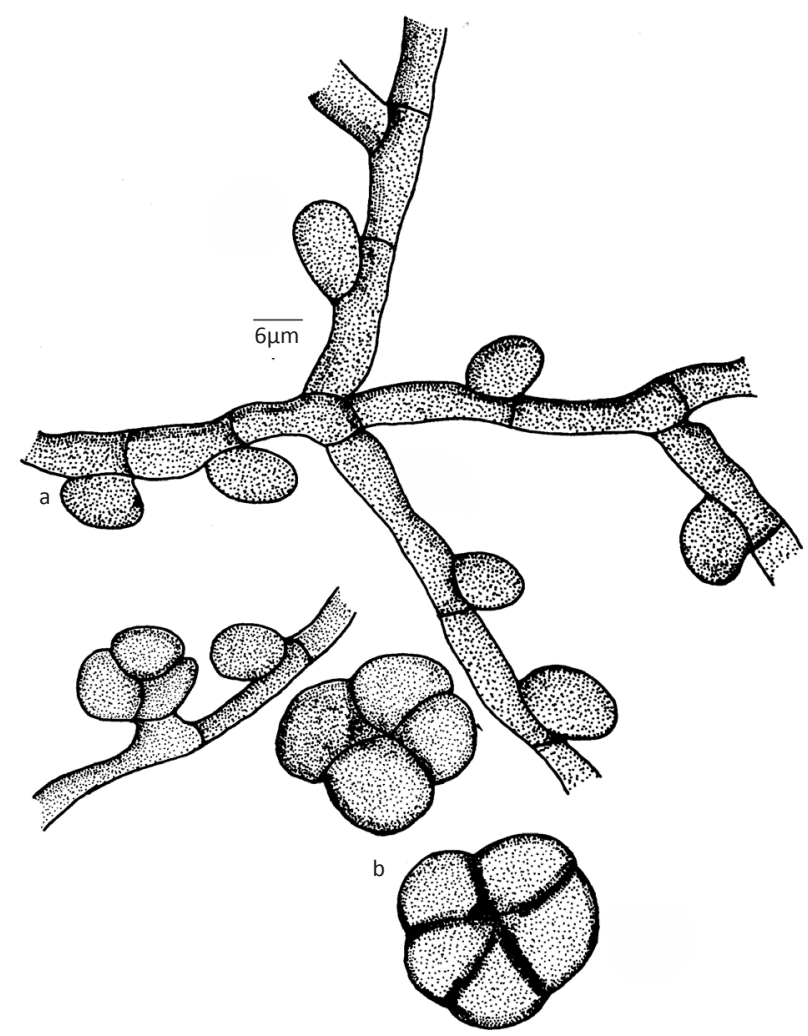

Figure 13. Sarcinella bischofiae sp. nov.

a - Appressoriate mycelium; b - Conidia of Sarcinella 
septa, 17-25 $\mu \mathrm{m}$ in diameter, wall smooth.

\section{Sarcinella pogostemonis Hosag., C. Jagath Thimmaiah \& A. Sabeena sp. nov.}

(Fig. 14) (MycoBank 803161)

Materials examined:Holotype:TBGT5784,16.xi.2010, on leaves of Pogostemon benghalensis (Brurm.f.) Kuntze (Lamiaceae), Madikeri, Kodagu, Karnataka, coll. C. Jagath Thimmiah.

Sarcinella colebrookiana Kamal \& Singh is known on Colebrookia oppositifolia from Uttar Pradesh (Hosagoudar 2011) but Sarcinella pogostemonis differs from it in having distinctly smaller spores (22-33 vs 30$50 \mu \mathrm{m})$.

Etymology: Specific epithet based on the host genus.

Colonies epiphyllous, thin, spread all over the leaf, confluent. Hyphae substraight to flexuous, branching opposite to irregular at acute to wide angles, closely reticulate, cells 25-30 x 5-8 $\mu \mathrm{m}$. Appressoria scattered, alternate, very rarely opposite, unicellular, globose, entire, $10-13 \times 8-10 \mu \mathrm{m}$. Conidia of Questieriella scattered, slightly curved, 3-septate, constricted at the septa, 32-42 x 7-10 $\mu \mathrm{m}$. Sarcinella conidiophores produced laterally from the hyphae, single, straight, mononematous, one septate; conidiogenous cells terminal, monoblastic, integrated, cylindrical. Sarcinella conidia blastic, terminal, mostly sessile, solitary, subspherical to spherical, sarciniform, 2-7 celled, constricted at the septa, 22-33 $\mu \mathrm{m}$ in diameter, wall smooth.

\section{Sarcinella securinegae Hosag., C. Jagath Thimmaiah \& A. Sabeena sp. nov.}

(Fig. 15) (MycoBank 803162)

Materials examined: TBGT 5757, 25.xi.2010, on leaves of Securingea leucopyrus (Willd.) Muell. (Euphorbiaceae), Hodur, Kodagu, Karnataka, coll. C. Jagath Thimmiah.

Based on the host specificity and presence of Questieriella state distinguishes this species.

Etymology: Specific epithet based on the host genus.

Colonies amphigenous, epiphyllous, thin, up to $2 \mathrm{~mm}$ in diameter, confluent. Hyphae brown, straight to substraight, branching opposite to irregular at acute to wide angles, closely reticulate, cells $18-27 \times 3-5 \mu \mathrm{m}$. Appressoria alternate to unilateral, unicellular, globose, entire, 5-7 x 5-10 $\mu \mathrm{m}$. Conidia of Questieriella few, scattered, slightly curved, 3-septate, constricted at the septa, germinate to form colonies, 30-35 x 7-10 $\mu \mathrm{m}$. Sarcinella conidiophores produced lateral to the hyphae,

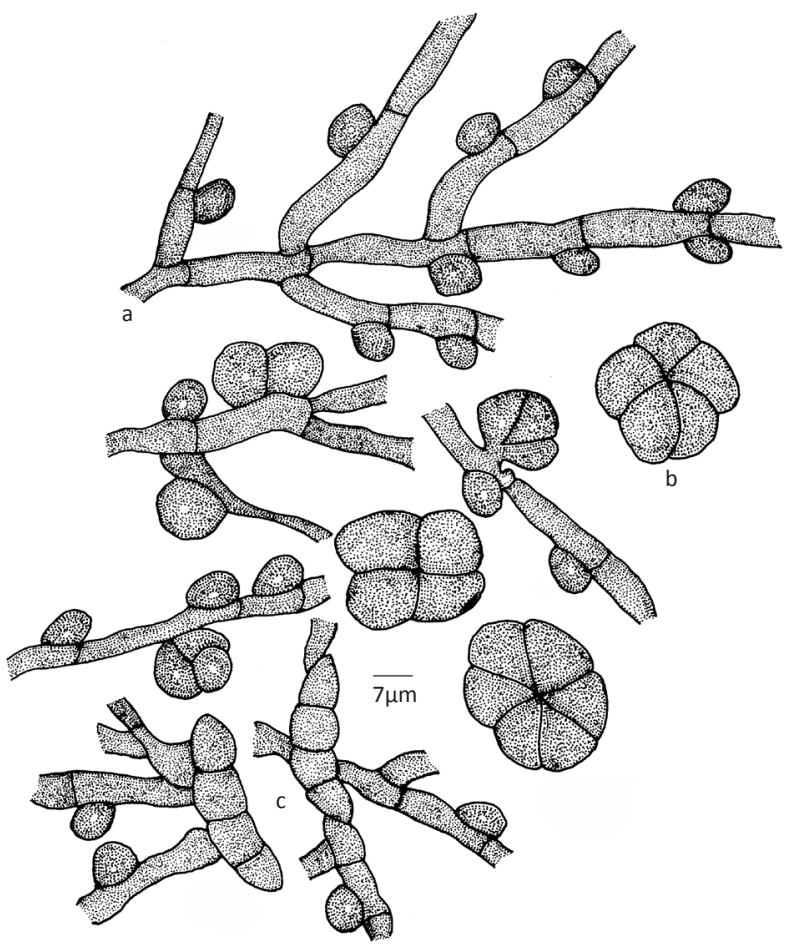

Figure 15. Sarcinella securinegae sp. nov.

a - Appressoriate mycelium; b - Conidia of Sarcinella

c - Germinating conidia of Questieriella

a - Appressoriate mycelium; b - Conidia of Sarcinella; c - Conidia of Questieriella 
single, straight, mononematous; conidiogenous cells terminal, monoblastic, integrated, cylindrical. Sarcinella conidia blastic, terminal, mostly sessile, solitary, ovate to globose, sarciniform, 2-8 celled, constricted at the septa, 18-30 $\mu \mathrm{m}$ in diameter, wall smooth.

\section{REFERENCES}

Doidge, E.M. (1942). A revision of the South African Microthyriaceae. Bothalia 4: 273-344.

Hosagoudar, V.B. \& T.K. Abraham (2000). A list of Asterina Lev. species based on the literature. Journal of Economic and Taxonomic Botany 24: 557-587.
Hosagoudar, V.B. (2011). The genus Schiffnerula in India. Plant Pathology \& Quarantine 1(2): 131-204.

Hosagoudar, V.B. (2012). Asterinales of India. Mycosphere 2(5): 617852.

Hosagoudar, V.B., N.P. Balakrishnan \& R.D. Goos (1996). Some Asterina species from southern India. Mycotaxon 59: 167-187.

Hosagoudar, V.B., C.K. Biju \& T.K. Abraham (2004). Studies on foliicolous fungi- II. Journal of Economic and Taxonomic Botany 28: 189.

Hosagoudar, V.B., J. Thomas \& A. Sabeena (2009). The Genus Lembosia on Humboldtia species in Kerala, India. Indian Journal of Science and Technology 2(6): 19-21.

Stevens, F.L. \& M.H. Ryan (1939). The Microthyriaceae. Illinois Biol. Monograph. 17: 1-138.

Theissen, F. (1913). Die Gattung Asterina. Bibliotheca Mycologia 10: 1-130. 